\title{
ARTICLE
}

\section{Factors accounting for variations in the parasitism by metacercariae (Digenea, Microphallidae) in the amphipod Apohyale hirtipalma (Gammaridea) in the Southeastern Pacific coast}

Factores que explican variaciones del parasitismo por metacercarias (Digenea, Microphallidae) en el anfípodo Apohyale hirtipalma (Gammaridea) en la costa del océano Pacífico sudoriental

\section{Claudia Hurtado-Ormeño ${ }^{1,2}$ and Mario George-Nascimento ${ }^{1,3}$}

\begin{abstract}
'Departamento de Ecología, Facultad de Ciencias, Universidad Católica de la Santísima Concepción, Casilla 297, Concepción, Chile. mgeorgen@ucsc.cl

${ }^{2}$ Programa de Magister en Ecología marina, Facultad de Ciencias, Universidad Católica de la Santísima Concepción, Concepción, Chile ${ }^{3}$ Centro de Investigación en Biodiversidad y Ambientes Sustentables (CIBAS). Universidad Católica de la Santísima Concepción, Concepción, Chile
\end{abstract}

\begin{abstract}
Resumen.- Se evaluó la relación parasítica por 2 morfoespecies de metacercarias (Microphallidae) en su segundo hospedador intermediario, el anfípodo Apohyale hirtipalma según el largo corporal y sexo del anfípodo, y la abundancia de aves costeras (hospedadores definitivos). La mortalidad de anfípodos parasitados fue evaluada a través de la relación varianza/promedio de la abundancia de cada morfoespecie de metacercaria con el tamaño corporal de los anfípodos. Cuatro localidades de muestreo fueron seleccionadas en la región del Biobío $\left(36^{\circ} \mathrm{S}\right)$, Chile, con diferencias contrastantes en la abundancia de hospedadores definitivos (Aves: Laridae). Se recolectaron 240 anfípodos desde pozas intermareales (60 en cada localidad de muestreo). La prevalencia total de metacercarias fue de 57,5\%, detectándose metacercarias de 2 subfamilias de Microphallidae (Microphallinae $28,3 \%$ y Maritrematinae $36,7 \%$ ), aun no identificadas a un nivel taxonómico más bajo. La prevalencia de ambas morfoespecies de metacercarias aumentaba con la longitud total de los anfípodos, aunque gran parte de sus variaciones estuvieron asociadas a la abundancia de aves costeras. La prevalencia de Microphallinae fue similar entre sexos en la relación al tamaño del cuerpo del hospedador, mientras que en los anfípodos machos parasitados con Maritrematinae mostraron mayor prevalencia que las hembras de similar tamaño corporal. Se determinó además que metacercarias Maritrematinae ocasionarían mayor mortalidad de anfípodos que Microphallinae. Las variaciones locales de abundancia de otros hospedadores involucrados en el ciclo de vida de estos digeneos, como también las condiciones ambientales locales y la conducta de los anfípodos, serían claves para comprender las variaciones de prevalencia y abundancia de estos parásitos.
\end{abstract}

Palabras clave: Abundancia de aves costeras, longitud corporal del hospedador, sexo del hospedador, mortalidad, Chile

\begin{abstract}
It was assessed the parasitic relationship between by 2 morphospecies of microphallid metacercariae and their second intermediate host, the amphipod Apohyale hirtipalma with the body length and sex of the hosts, and the abundance of shore birds (definitive hosts). Amphipod mortality induced by the parasites was assessed through the relationship between the variance/ mean parasite abundance ratio with host body length for each metacercariae morphospecies. Four sites at the Biobío Region $\left(36^{\circ} \mathrm{S}\right)$, Chile, were selected because of contrasting abundance of potential definitive hosts (Aves: Laridae), from where 240 amphipods were collected from intertidal pools (60 in each sampling locality). Total prevalence was $57.5 \%$ and metacercariae found, belonged to 2 unidentified morphospecies of microphallid subfamilies (Microphallinae, 28.3\% and Maritrematinae, $36.7 \%$ ). The prevalence and abundance of metacercariae increased with the amphipod body, although their variations were associated to the abundance of shorebirds. The prevalence of Microphallinae did not have differences among sexes in their relationship with the host body length, while among Maritrematinae, male amphipods showed higher prevalence than females of similar body length. It was also determined that Maritrematinae would cause more mortality than Microphallinae. Local variations of the abundance of other hosts involved in the microphallid life cycles as well as of prevailing local environmental conditions and amphipod behavior may be keys for a better understanding of the abundance and prevalence variations of these parasites.
\end{abstract}

Key words: Shorebird abundance, host body length, host sex, parasite identity, mortality, Chile 


\section{INTRODUCTION}

Trematodes (Platyhelminthes: Digenea) are parasites with indirect life cycles that usually occupy vertebrates as definitive hosts, while the first intermediate hosts are mostly mollusks, for which they are usually highly specific (Noble \& Noble 1965). The range of second intermediate hosts is wider than for first intermediate hosts, which include plants, mollusks, arthropods and vertebrates (Noble \& Noble 1965). More specifically, among some species of Microphallidae (Digenea), there is a relatively high degree of specificity for the first intermediate host (Galaktionov et al. 2012), and can occupy a wide range of species in second intermediate hosts (Wojdak et al. 2013).

Some factors, such as body size and sex of the hosts, and the abundance of definitive hosts are considered as potentially relevant to explain the variations in magnitude of parasitism by metacercariae in amphipods, as well as the parasite induced host mortality. These parasitoses are usually cumulative, thus a greater prevalence and abundance of parasites is expected in larger amphipods (Crofton 1971, Kennedy 1975). However, amphipod size co-varies with sex, since females attain smaller body sizes than males. It is also expected that gender per se may be a factor associated with variations of parasitism, which may be due to differences in behavior, innate susceptibility or defense responses (Bryan-Walker et al. 2007, Durieux et al. 2012, Stone \& Moore 2014). In addition, some trematodes have been reported as causing differential mortality in amphipods according to the host species identity, sex and body length (Rousset et al. 1996). Consequently, it is expected that the prevalence and abundance of microphallids are associated positively with the abundance of their common definitive hosts, which are shorebirds (Cremonte \& Martorelli 1998, Fredensborg et al. 2004, Martorelli et al. 2004, Fredensborg \& Poulin 2005, González-Acuña et al. 2009, Koehler et al. 2010a), including gull species Larus spp. In fact, the importance of the abundance of definitive hosts on the degree of parasitism in amphipod intermediate hosts from intertidal systems has already been acknowledged, though the spatial scale at which they are correlated remains controversial (Smith 2001, Latham \& Poulin 2003, Fredensborg et al. 2006, Smith 2007, Thieltges et al. 2009, Levakin et al. 2013, Leiva et al. 2015).

In this study it is evaluated the relative importance that intermediate host length and sex, as well as abundance of definitive hosts (shorebirds) may have on the prevalence and abundance of parasitism by metacercariae (Digenea, Microphallidae) in their second intermediate host: the amphipod Apohyale hirtipalma (Dana, 1852) (Gammaridea). This is a common inhabitant of intertidal pools on the central Chilean coast, where the amphipod Hyale grandicornis has been recorded as harboring microphallid metacercariae (Muñoz 2005), as elsewhere for amphipods (Fredensborg et al. 2004, Martorelli et al. 2004). In addition, it is examined if there is some evidence supporting that parasite induced host mortality occurs in this system (Rousset et al. 1996).

\section{MATERIALS AND METHODS}

The study was carried out in 4 locations repeatedly visited before sampling to know the abundance of birds and amphipods in rocky tide pools, and finally selected to represent a gradient in the abundance of gulls (Laridae) in the Biobío region, Chile. There were 2 kinds of locations: those having large permanent and resident flocks and others with ephemeral small groups. The sampling localities in visually decreasing order of shorebird abundance were Maule (3659' $52^{\prime}$ 'S $\left.; 7^{\circ} 11^{\prime} 18^{\prime \prime} \mathrm{W}\right)$, Lirquén

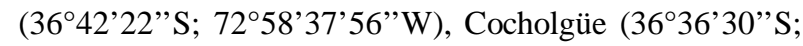
$\left.72^{\circ} 58^{\prime} 46^{\prime \prime} \mathrm{W}\right)$ and Coliumo (36 31'26”'S; $\left.72^{\circ} 58^{\prime} 4^{\prime \prime} \mathrm{W}\right)$. After selection of sampling locations, the abundance of seagulls in each location was estimated twice per day during 3 consecutive days, in 4 dates between December 2013 and January 2014, by direct counting (expressed as the number of sightings in a $4 \mathrm{~h}$ observation period) or by counting on photographs taken at regular intervals of $2 \mathrm{~h}$ during daylight. The bird sample group included the combined abundance of 2 species of Larus present at the study sites, i.e., Larus dominicanus (Lichtenstein, 1823) and L. pipixcan (Wagler, 1831). In all, we gathered 6 quantitative assessments of bird abundance for each location.

After the assessment of bird abundance, 60 amphipod specimens were collected from rocky tidepools at each location using hand nets. No attempt was made to evaluate the abundance of amphipods at each location. Individuals of the A. hirtipalma species were identified according to González (1991) and Thiel \& Hinojosa (2002). The body length of each amphipod was measured with a vernier caliper of $0.1 \mathrm{~mm}$ accuracy, while the sex was determined by visual inspection. The hosts were meticulously dissected with needle-nose pliers under a stereomicroscope and all of the metacercariae found were collected. Taxonomic determination of the metacercariae followed criteria used by Muñoz (2005), and was also aided with artificial excystment, incubating in a physiological saline solution and bile salts at an ambient temperature over $24 \mathrm{~h}$.

Statistical analysis considered a one-way analysis of variance of the abundance of seagulls in the 4 sampling localities, and a Tukey a posteriori test. AZ test for 2 proportions was used to compare the prevalence of the 2 morphospecies of metacercariae found in amphipods across the 4 locations. A Chi-square test was applied to evaluate whether co-occurrence between morphospecies of metacercariae departed from random expectations. A logistic regression covariance analysis was used 
to evaluate the relationship between the probability of finding metacercariae of each morphospecies with the total length of $A$. hirtipalma, and according to the sex of the amphipod and the abundance of seagulls. An OLS covariance analysis was used to assess the relationship between the abundance of $\log _{10}(x+1)$ transformed data of each morphospecies of metacercariae with the total length of the amphipod, the abundance of seagulls and the sex of the amphipod. To assess the host sex effect, residuals of the relationship between parasite abundance with the host body length were compared between male and female amphipods. To detect parasite induced host mortality, two approaches were employed. First, the analysis of covariance included a quadratic term, and second, the behavior of the variance/mean ratio of parasite abundance, for each parasite taxon, was examined according the body length of the amphipod hosts, following the protocol given by Rousset et al. (1996). Broadly speaking, these authors state that highly overdispersed distribution of parasite loads increase through host age (i.e., body length) in those parasites with cumulative infections that do not induce host mortality. In contrast, among pathogenic parasites that cumulate through host ontogeny, the mortality they induce can eliminate heavily infected hosts, thus leading to a decline in the mean abundance, and in rate of increase of the variance/mean ratio among larger (older) hosts.

\section{RESUlts}

As expected, the abundance of birds in all the selected sampling localities showed significant differences one another $\left(\mathrm{F}_{(3,20)}=\right.$ 136.22, Tukey-test, $P \leq 0.01$, Table 1 ). Also as expected, male amphipods were larger than females (male average $=9.54 \mathrm{~mm}$, s. $d .=1.65, n=128$, female average $=6.78 \mathrm{~mm}$, s. $d .=1.32$, $\mathrm{n}=112$, Table 1 ).

Overall, more than half (57.5\%) of the 240 amphipods harbored microphallid metacercariae belonging to 2 subfamilies, namely Microphallinae (28.3\%) and Maritrematinae (36.7\%), with significantly different prevalences (two-proportion comparison test, $z=-2.93, P=0.002$, Table 1 ). Metacercariae did not show a separate pattern of co-occurrence in the hosts because out of 138 amphipods parasitized, 25 harbored both morphospecies of metacercariae (Pearson Chi-square test, $\chi^{2}=$ 1.02$, d. f. $=2, P=0.31)$.

The probability of finding Microphallinae metacercariae increased with the total length of A. hirtipalma, but not that of Maritrematinae (Microphallinae: Wald $\chi^{2}=19.91$, d. f. $=1, P$ $<0.0001$, Maritrematinae: Wald $\chi^{2}=1.80$, d. f. $=1, P=0.180$, Fig. 1). Maximum prevalence of Maritrematinae according to the host total length peaks around $60 \%$, while Microphallinae levels reach up to $c a .90 \%$ (Fig. 1).

Most of the variation in the presence of each morphospecies of metacercariae was associated to the abundance of shorebirds (Table 1). However, this was not a tight association for Maritrematinae because localities with intermediate abundance of seagulls (Cocholgüe and Lirquén) have higher prevalence than the locality with the highest abundance of seagulls (Maule, Table 1), which furthermore was not different to the locality with lowest abundance of seagulls (Coliumo, Table 1). In contrast, Microphallinae showed a better fit to seagull abundance (Table 1).

Table 1. Seagull abundance (s.d.: standard deviation), body length of A. hirtipalma according to sex, and prevalence and abundance of 2 morphospecies of microphallid metacercariae (Micro: Microphallinae, Marit: Maritrematinae). $n=n u m b e r$ of amphipods. Letters besides the number of seagulls indicate different means after a Tukey test / Abundancia de gaviotas, longitud corporal de A. hirtipalma según el sexo, y prevalencia y abundancia de 2 morfoespecies de metacercarias de microfálidos (Micro: Microphallinae, Marit: Maritrematinae). $n=$ número de anfípodos. Las letras al lado de los números de gaviotas indican promedios diferentes luego de una prueba de Tukey

\begin{tabular}{|c|c|c|c|c|c|c|c|c|}
\hline \multirow{2}{*}{$\begin{array}{c}\text { Seagull } \\
\text { abundance }\end{array}$} & \multirow{2}{*}{ Number } & \multirow{2}{*}{$\begin{array}{l}\text { Amphipod' } \\
\text { s sex }\end{array}$} & \multirow{2}{*}{$\mathrm{n}$} & \multirow{2}{*}{$\begin{array}{l}\text { Total length } \\
\text { (mm) }\end{array}$} & \multicolumn{2}{|c|}{ Prevalence $(\%)$} & \multicolumn{2}{|c|}{ Abundance (s. d.) } \\
\hline & & & & & Micro & Marit & Micro & Marit \\
\hline High & $368,2(30,6) \mathrm{A}$ & q & 29 & $6.33 \pm 1.79$ & 31.0 & 0 & $0.72(1.33)$ & 0 \\
\hline (Maule) & & $0^{\pi}$ & 31 & $10.79 \pm 1.35$ & 96.8 & 35.5 & $9.29(5.37)$ & $0.87(2.20)$ \\
\hline \multirow{2}{*}{$\begin{array}{l}\text { Medium-high } \\
\text { (Lirquén) }\end{array}$} & $269,3(34,8) \mathrm{B}$ & q & 20 & $7.31 \pm 0.77$ & 0 & 7.0 & 0 & $1.75(2.05)$ \\
\hline & & $0^{\pi}$ & 40 & $9.15 \pm 1.41$ & 10.0 & 82.5 & $0.32(1.14)$ & $4.55(5.74)$ \\
\hline \multirow{2}{*}{$\begin{array}{l}\text { Medium-low } \\
\text { (Cocholgüe) }\end{array}$} & $203,3(19,4) \mathrm{C}$ & 우 & 33 & $6.40 \pm 1.23$ & 15.2 & 30.3 & $0.15(0.36)$ & $0.54(1.01)$ \\
\hline & & $0^{\pi}$ & 27 & $9.06 \pm 1.74$ & 63.0 & 63.0 & $2.51(3.86)$ & $1.89(2.56)$ \\
\hline \multirow{2}{*}{$\begin{array}{c}\text { Low } \\
\text { (Coliumo) }\end{array}$} & $78,2(9,1) \mathrm{D}$ & q & 30 & $7.30 \pm 0.77$ & 0 & 0 & 0 & 0 \\
\hline & & $0^{\pi}$ & 30 & $9.19 \pm 1.41$ & 6.6 & 10.0 & $0.20(0.80)$ & $0.20(0.66)$ \\
\hline
\end{tabular}



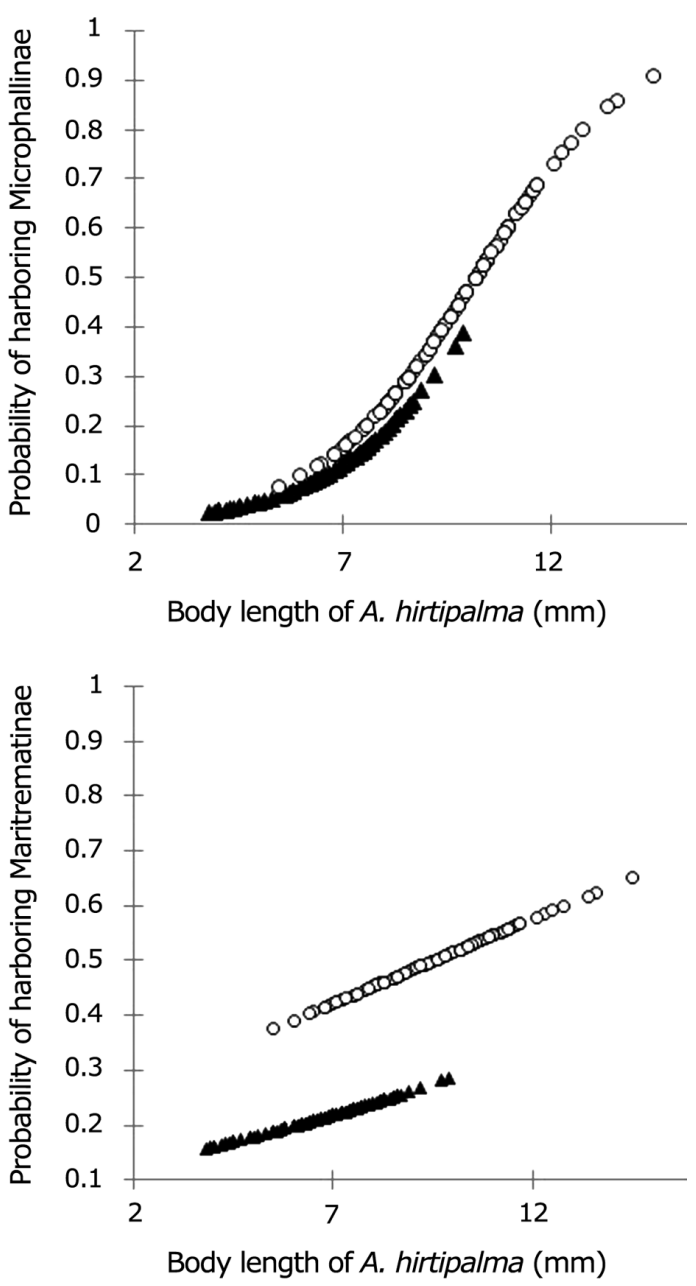

Figure 1. Predicted probabilities of finding 2 morphospecies of microphallid metacercariae in the amphipod $A$. hirtipalma according to their total length $(\mathrm{mm})$ and sex (males: white circles, females: black triangles) / Probabilidades de encontrar 2 morfoespecies de metacercarias de microfálidos en el anfípodo A. hirtipalma según su longitud total $(\mathrm{mm})$ y sexo (machos: círculos blancos, hembras: triángulos negros)

After accounting for variations due to amphipod total length, the sex of the amphipod revealed to be a relevant factor to explain the probability of finding Maritrematinae metacercariae only (Maritrematinae: Wald $\chi^{2}=11,36$, d.f. $=1, P<0.001$, Microphallinae: Wald $\chi^{2}=0.416$, d. f. $=1, P=0.519$, Fig. 1 ). That is, males had a higher prevalence than females of similar size. This result implies that host sex per se is a factor in the parasitism by Maritrematinae. This is also reflected in that all 25 amphipods that harbored both morphospecies of metacercariae were males, what departs significantly from random expectations (Pearson $\chi^{2}$ with Yates correction for continuity $=9.978$, d.f. $=1, P=0.002$ ).
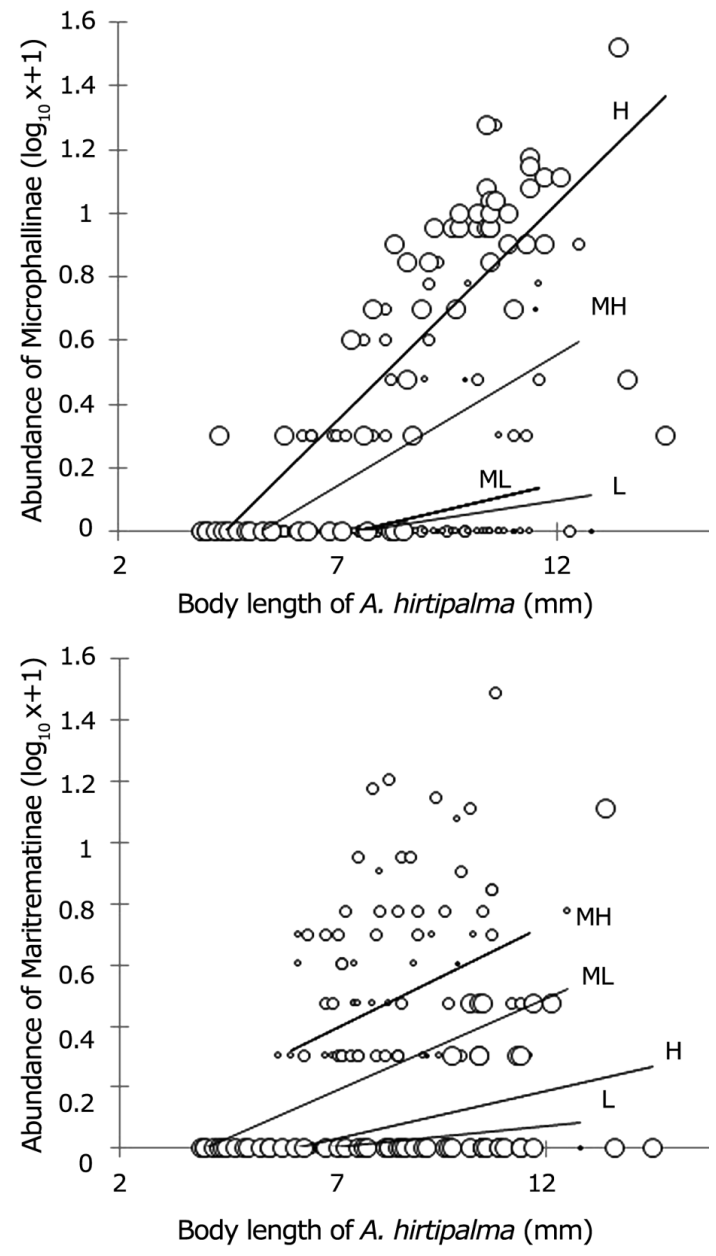

Figure 2. Dispersion diagrams of the relationship between the body length of $A$. hirtipalma $(\mathrm{mm})$ with the abundance $\log _{10}(x+1)$ of 2 morphospecies of microphallid metacercariae. Size of circles are 4 levels of seagull abundance. Lines are OLS regressions for each level of seagull abundance / Diagramas de dispersión de la relación entre la longitud corporal de A. hirtipalma $(\mathrm{mm})$ con la abundancia $\log _{10}$ $(x+1)$ de 2 morfoespecies de metacercarias de microfálidos. El tamaño de los círculos indica los 4 niveles de abundancia de gaviotas. Las líneas son las regresiones OLS para cada nivel de abundancia de gaviotas

The total abundance of metacercariae varied between 0 and 44 (average $=3.0$, s.d. $=5.11, \mathrm{n}=240)$. Non significant differences in the abundance of Maritrematinae and Microphallinae were found (Mann-Whitney two-tailed test, $P$ $=0.247$ ). Also, there was no significant correlation between their abundances (Spearman correlation coefficient, $\mathrm{r}_{\mathrm{s}}=0.01$, $P=0.876, \mathrm{n}=240$ ). However, both were positively correlated with the amphipod total length, though differently for each morphospecies of metacercariae (Fig. 2). 
Table 2. Summary table of the analysis of the covariance of the abundance $\left(\log _{10} x+1\right)$ of Microphallinae and Maritrematinae metacercariae according to the body length and sex of the amphipod A. hirtipalma, and the abundance of definitive hosts (Aves: Laridae)/ Tabla resumen del análisis de la covarianza de la abundancia $\left(\log _{10} x+1\right)$ de metacercarias Microphallinae y Maritrematinae según la longitud corporal y sexo del anfípodo A. hirtipalma, y la abundancia de hospedadores definitivos (Aves: Laridae)

\begin{tabular}{lcrrrr}
\hline Source of variation & $\begin{array}{c}\text { Degrees } \\
\text { of } \\
\text { freedom }\end{array}$ & $\begin{array}{c}\text { Type I } \\
\text { sum of } \\
\text { squares }\end{array}$ & $\begin{array}{c}\text { Mean } \\
\text { squares }\end{array}$ & F & $P$ \\
\hline Microphallinae & & & & & \\
$\quad$ Amphipod length & 1 & 8.63 & 8.63 & 234.24 & $<0.0001$ \\
Bird abundance (1) & 3 & 11.00 & 3.67 & 99.49 & $<0.0001$ \\
Amphipod sex (2) & 1 & 0.52 & 0.52 & 13.98 & $<0.0002$ \\
(1)*(2) & 3 & 3.86 & 1.29 & 34.88 & $<0.0001$ \\
Maritrematinae & 1 & 1.69 & 1.69 & 28.05 & $<0.0001$ \\
Amphipod length & 1 & 7.87 & 2.62 & 43.44 & $<0.0001$ \\
Bird abundance (1) & 3 & 0.22 & 0.22 & 3.71 & 0.0553 \\
Amphipod sex (2) & 1 & 0.31 & 0.10 & 1.72 & 0.1635 \\
(1)*(2) & 3 & & & & \\
\hline
\end{tabular}

The slope of the relationship between the abundance of Microphallinae and the total length of the host was greater in locations with a higher abundance of birds $\left(\mathrm{F}_{(3,231)}=99.49\right.$, $P=0.0001)$. Something similar occurred with the interaction between the sex of the amphipod and the abundance of birds $\left(\mathrm{F}_{(3,231)}=13.98, P=0.0001\right.$, Table 2, Fig. 2). This model accounted for $73.8 \%$ of the variance of the abundance of Microphallinae. A model including a quadratic term for total length, and all interaction terms, accounted for $75.6 \%$, what is statistically significant $(P<0.05)$. In contrast, the relationship between the abundance of Maritrematinae and the total length of the host only demonstrated a greater slope in locations with a higher abundance of birds $\left(\mathrm{F}_{(3,231)}=43.44, P=0.0001\right)$, but it was not associated with the sex of the amphipod $\left(\mathrm{F}_{(1,231)}=\right.$ $3.71, P=0.055$, Table 2, Fig. 2). This model accounted for $42.0 \%$ of the variance of the abundance of Maritrematinae. A full model including a quadratic term for total length and all interaction terms accounted for $44.5 \%$ what is also statistically significant $(P<0.05)$.

The variance/mean ratio of parasite abundance with host total length increases monotonically for Microphallinae, whereas decreases among largest hosts harboring Maritrematinae (Fig. 3).

\section{Discussion}

Only one previous study recorded metacercariae in the amphipod H. grandicornis from Chile (Muñoz 2005). Therefore, the present study is the first report on quantitative patterns of parasitism in amphipods from the Southeastern Pacific Coast. We do not know the specific identity of these digeneans but these metacercariae
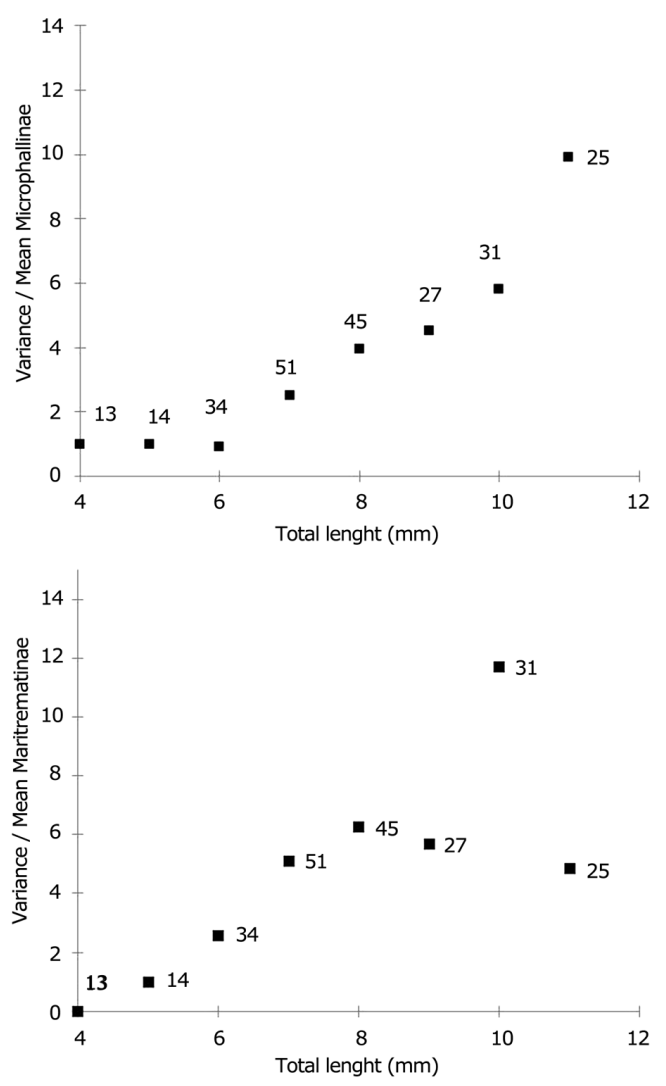

Figure 3. Dispersion diagrams of the relationship between the variance/ mean ratio of parasite abundance with total length classes of $A$. hirtipalma. Numbers upon markers are absolute frequencies / Diagramas de dispersión de la relación entre la varianza/ promedio de la abundancia parasitaria con las clases de longitud total de A. hirtipalma. Los números sobre los marcadores son frecuencias absolutas 
may well belong to one of the 3 species of Microphallidae recorded at adult stage in $L$. dominicanus in the Biobío region, namely Maritrema eroliae, Microphallus nicolli and Odhneria odhneri (González-Acuña et al. 2009), or to species recorded in seagulls in South America (e.g., Etchegoin et al. 1996, Etchegoin \& Martorelli 1997, Cremonte \& Martorelli 1998), or yet to be described.

The finding that the maximum length of A. hirtipalma is important to explain the degree of parasitism by metacercariae is not a surprise. The increase in abundance with the total length of the amphipod has been recorded previously in other species of Microphallidae (Fredensborg et al. 2004). As a result of the accumulation of the parasites through host ontogeny (Poulin \& Mouritsen 2003, Fredensborg et al. 2004), is due to time of exposure to cercariae, i.e., hosts with the greatest length have been exposed for longer time lapses than the juvenile amphipods (Fredensborg et al. 2005), which would increase the probability of being infected with parasites and increase the abundance of parasites within the host. However, this relationship was different between the 2 morphospecies of metacercariae (Figs. 1 and 2), indicating that the interface between the amphipod and the mollusk(s) producing cercariae is also different. That is, other factors such as the composition of mollusk species assemblages in each location, which are necessary as first intermediate hosts, may also be linked to the differences observed in the prevalence between metacercariae in amphipods, since species in the Microphallidae family are capable of using a broad spectrum of crustaceans as second intermediary hosts (Etchegoin et al. 1996, Etchegoin \& Martorelli 1997, Fredensborg et al. 2004, Koehler et al. 2010b, Leiva et al. 2015). As a result, the joint abundance of species required as links for the development of the Microphallidae's larval stage (mollusks and amphipods) could together be considered a better tool for predicting and evaluating variations in the degrees of digenean infection in second intermediate hosts (Lagrue \& Poulin 2015).

Finally, it must be considered that once the effect of maximum length is included in the statistical model, the sex of the amphipod is a relevant factor to explain variations in the abundance of Microphallinae, but not in the abundance of Maritrematinae metacercariae. These variations could be associated to differences in the behavior between sexes in A. hirtipalma as well as by different effects of the parasites on hosts according to their sex. Other sources of variation of parasitism are feeding habits of seagulls which are known to include a wide variety of prey, and that changes occur according to the seasons, or to the local prey availability (Bahamondes \& Castilla 1986, Bertellotti \& Yorio 1999). In fact the relative importance of parasite species and local factors must be a mosaic of combinations leading to this level of heterogeneity in parasitism among intertidal invertebrates.
Future studies in Chile should consider in more depth the eventual effect of these parasites on the survival of A. hirtipalma, as noted elsewhere as a short-term cause of mortality when found in high abundance, what could have consequences for the population dynamics of amphipods (Rousset et al. 1996, Thomas et al. 1998, Meisser \& Bick 1999, Fredensborg et al. 2004, Leung $\&$ Poulin 2006, Studer 2011). Evidence of parasite induced host mortality in our data suggests that it is more likely to occur among Maritrematinae. This is so because the inclusion of a quadratic term in the linear model resulted in significant but mild increases in the amount of variance of abundance explained in both morphospecies, and because the trend of the variance/mean ratio of parasite abundance with host total length decreases among largest hosts harboring Maritrematinae, whereas for Microphallinae the trend is monotonic (Fig. 3).

\section{ACKNOWLEDGMents}

Thanks are due to the critical contribution of referees and the editor that significantly improved the original version. This study was financed by Grant FONDECYT 1130304 to MG-N.

\section{LITERATURE CITED}

Bahamondes I \& JC Castilla. 1986. Predation of marine invertebrates by the Kelp Gull Larus dominicanus in an undisturbed intertidal rocky shore of central Chile. Revista Chilena de Historia Natural 59: 65-72.

Bertellotti M \& P Yorio. 1999. Spatial and temporal patterns in the diet of the Kelp Gull in the Northern Chubut, Patagonia. Condor 101:790-798.

Bryan-Walker K, TLF Leung \& R Poulin. 2007. Local adaptation of immunity against a trematode parasite in marine amphipod populations. Marine Biology 152: 687-695.

Cremonte F \& S Martorelli. 1998. Description of a new species of Maritrema (Digenea: Microphallidae) from Larus dominicanus (Aves: Laridae) in Buenos Aires coast, Argentina. Folia Parasitologica 45: 230-232.

Crofton H. 1971. A quantitative approach to parasitism. Parasitology 62: 179-193.

Durieux R, T Rigaud \& V Médoc. 2012. Parasite-induced suppression of aggregation under predation risk in a freshwater amphipod: sociality of infected amphipods. Behavioural Processes 91: 207-213.

Etchegoin JA \& S Martorelli. 1997. Description of a new species of Maritrema (Digenea: Microphallidae) from Mar Chiquita coastal lagoon (Buenos Aires, Argentina) with notes on its life cycle. The Journal of Parasitology 83: 709-713.

Etchegoin JA, S Martorelli \& NH Sardella. 1996. Nuevo registro de Microphallus szidati Martorelli, 1986 (Digenea: Microphallidae) en Mar Chiquita (Buenos Aires, Argentina). Neotropica 42: 117-118. 
Fredensborg B \& R Poulin. 2005. In vitro cultivation of Maritrema novaezealandensis (Microphallidae): the effect of culture medium on excystation, survival and egg production. Parasitology Research 95: 310-313.

Fredensborg BL, KN Mouritsen \& R Poulin. 2004. Intensity-dependent mortality of Paracalliope novizealandiae (Amphipoda: Crustacea) infected by a trematode: Experimental infections and field observations. Journal of Experimental Marine Biology and Ecology 311: 253-265.

Fredensborg BL, KN Mouritsen \& R Poulin. 2005. Impact of trematodes on host survival and population density in the intertidal gastropod Zeacumantus subcarinatus. Marine Ecology Progress Series 290: 109-117.

Fredensborg BL, KN Mouritsen \& R Poulin. 2006. Relating bird host distribution and spatial heterogeneity in trematode infections in an intertidal snail-from small to large scale. Marine Biology 149: 275-283.

Galaktionov KV, I Blasco-Costa \& PD Olson. 2012. Life cycles, molecular phylogeny and historical biogeography of the 'pygmaeus' microphallids (Digenea: Microphallidae): widespread parasites of marine and coastal birds in the Holarctic. Parasitology 139: 1346-1360.

González E. 1991.The genus Hyale in Chile. Spixiana 14: 125142.

González-Acuña D, F Cerda, J López, R Ortega, C Mathieu \& M Kinsella. 2009. Checklist of the helminths of the kelp gull, Larus dominicanus (Aves: Laridae), with new records from Chile. Zootaxa 2297: 27-43.

Kennedy CR. 1975. Ecological animal parasitology, 163 pp. Blackwell Scientific Publications, Oxford.

Koehler A, A Gonchar \& R Poulin. 2010a. Genetic and environmental determinants of host use in the trematode Maritrema novaezealandensis (Microphallidae). Parasitology 138: 100-106.

Koehler AV, YP Springer, DB Keeney \& R Poulin. 2010b. Intra and interclonal phenotypic and genetic variability of the trematode Maritrema novaezealandensis. Biological Journal of the Linnean Society 103: 106-116.

Lagrue C \& R Poulin. 2015. Spatial covariation of local abundance among different parasite species: the effect of shared hosts. Parasitology Research 114: 3637-3643.

Latham ADM \& R Poulin. 2003. Spatiotemporal heterogeneity in recruitment of larval parasites to shore crab intermediate hosts: the influence of shorebird definitive hosts. Canadian Journal of Zoology 81: 1282-1291.

Leiva N, M George-Nascimento \& G Muñoz. 2015. Carga parasitaria en crustáceos decápodos de la costa central de Chile: ¿existe alguna asociación con la abundancia de los hospedadores definitivos? Latin American Journal of Aquatic Research 43: 726-738.
Leung TLF \& R Poulin. 2006. Effects of the trematode Maritrema novaezealandensis on the behaviour of its amphipod host: adaptive or not? Journal of Helminthology 80: 271-275.

Levakin IA, KE Nikolaev \& KV Galaktionov. 2013. Longterm variation in trematode (Trematoda, Digenea) component communities associated with intertidal gastropods is linked to abundance of final hosts. Hydrobiologia 706: 103-118.

Martorelli S, B Fredensborg, K Mouritsen \& R Poulin. 2004. Description and proposed life cycle of Maritrema novaezealandensis $\mathrm{sp}$. $\mathrm{n}$. (Microphallidae) parasitic in redbilled gulls, Larus novaehollandiae scopulinus, from Otago harbor, South Island, New Zealand. The Journal of Parasitology 90: 272-277.

Meisser K \& A Bick. 1999. Mortality of Corophium volutator (Amphipoda) caused by infestation with Maritrema subdolum (Digenea: Microphallidae). Diseases of Aquatic Organisms 35:47-52.

Muñoz G. 2005. Metacercarias de la familia Microphallidae (Trematoda: Digenea) en el anfípodo Hyale grandicornis en la costa de Maule, Chile Central. Parasitología Latinoamericana 60: 165-169.

Noble E \& G Noble. 1965. Parasitología; biología de parásitos animales, 675 pp. Editorial Interamericana, México.

Poulin R \& K Mouritsen. 2003. Large-scale determinants of trematode infections in intertidal gastropods. Marine Ecology Progress Series 254: 187-198.

Rousset F, F Thomas, T De Meeûs \& F Renaud. 1996. Inference of parasite-induced host mortality from distributions of parasite loads. Ecology 77: 2203-2211.

Smith NF. 2001. Spatial heterogeneity in recruitment of larval trematodes to snail intermediate hosts. Oecologia 127: 115122.

Smith NF. 2007. Associations between shorebird abundance and parasites in the sandcrab, Emerita analoga, along the California coast. The Journal of Parasitology 93: 265-273.

Stone CF \& J Moore. 2014. Parasite-induced alteration of odour responses in an amphipod-acanthocephalan system. International Journal for Parasitology 44: 969-975.

Studer A. 2011. Parasitism in a changing world: The intertidal trematode Maritrema novaezealandensis and its hosts. Thesis of Doctor of Philosophy, University of Otago, Dunedin, $209 \mathrm{pp}$.

Thiel M \& I Hinojosa. 2002. Peracarida-Anfípodos, Isópodos, Tainadáceos \& Cumáceos. En: Haüsserman V \& G Försterra (eds). Fauna marina bentónica de la Patagonia chilena, pp. 671-738. Nature in Focus, Santiago.

Thieltges DW, BL Fredensborg \& R Poulin. 2009. Geographical variation in metacercarial infection levels in marine invertebrate hosts: parasite species character versus local factors. Marine Biology 156: 983-990. 
Thomas F, M Villa, I Montoliu, F Santalla, F Cezilly \& F

Renaud. 1998. Analyses of a debilitating parasite (Microphallus papillorobustus, Trematoda) and its "hitchhicker" parasite (Maritrema subdolum, Trematoda) on survival of their intermediate host (Gammarus insensibilis, Amphipoda). Proceedings of the Helminthological Society of Washington 65: 1-5.
Wojdak J, L Clay, S Moore, T Williams \& L Belden. 2013. Echinostoma trivolvis (Digenea: Echinostomatidae) second intermediate host preference matches host suitability. Parasitology Research 12: 799-805.

Received 2 September 2015 and accepted 6 January 2016

Associated Editor: Gabriela Muñoz C. 